\title{
The effect of cutting times on goat's rue (Galega orientalis Lam.) leys
}

\author{
PERTTU VIRKAJÄRVI ${ }^{1}$ and EERO VARIS \\ University of Helsinki, Department of Crop Husbandry \\ SF-00710 Helsinki, Finland
}

\begin{abstract}
The effect of four different cutting times, both in spring and autumn, on goat's rue was studied at Viikki Experimental farm of the University of Helsinki in 1983-89.

Goat's rue showed good persistence. The plots remained in good condition, the average yield being even in the sixth year $9000 \mathrm{~kg}$ DM per hectare. The development of goat's rue starts early in the spring. The growth rate and development of CP content are similar to those of red clover. The development of CF is, however, more similar to grasses. Thus, the crude fiber content limits the cutting times of goat's rue more than the changes in crude protein content.

The most suitable cutting time in spring is at the beginning of flowering in mid-June, and in autumn during the second week of September. With this management a yield of $8360 \mathrm{~kg}$ DM per hectare per year was reached during the experimental years. The pooled CP content was $19.9 \%$ and the CP yield was $1660 \mathrm{~kg} / \mathrm{ha}$. The CF content was in the first cut $27.9 \%$ and in the second cut $29.1 \%$. The amount of weeds in the five to six year leys was $12-18 \%$.
\end{abstract}

Index words: Galega orientalis, goat's rue, pasture legume

\section{Introduction}

Goat's rue, Galega orientalis Lam., is a perennial forage legume originating from the mountain regions of Caucasia. It was brought to Finland from Estonia, where its cultivation area has increased in recent years up to 3700 ha (RAIG 1988). The possibilities of goat's rue cultivation in Finland and the properties of the plant have been discussed by VARIS (1986).

I Present address: Agric. Res. Center, Karelia Res. Sta. SF-82600 Tohmajărvi, Finland.
Recently, the content of vasicine, a bitter tasting alkaloid, was found to be very low in the population cultivated in Finland (LAAKSo et al. 1990).

Goat's rue is said to be a very permanent forage legume (RAIG 1988). This aspect was in mind when this seven year field trial was established at Viikki in 1983. The objects of major interest were the effects of cutting times on the quality of the yield as well as on the persistence and the condition of the ley. In this paper the cutting time effects on the quantity and quality of the yield as well as the persist- 
ence of goat's rue are discussed. The effect of climatic factors and annual variation will be discussed in the next paper.

\section{Material and methods}

The field trials were conducted at Viikki experimental farm of the University of Helsinki, Department of Crop Husbandry in 19831989. The trial was arranged in split-plot design with three replicates. The plot size was $10 \mathrm{~m}^{2}$.

Main plot (A): cutting time of the spring cut

1. beginning of June (before blooming)

2. mid-June (at the beginning of blooming)

3. end of June (full blooming)

4. beginning of July (at the end of blooming)

Sub-plot (B): cutting time of the autumn cut

1. end of August

2. beginning of September

3. end of September

4. beginning of October (at the end of growing season)

The trial was established without cover crop on $6 \mathrm{May}, 1983$ in rows $12.5 \mathrm{~cm}$ apart. The seeding rate was $30 \mathrm{~kg} / \mathrm{ha}$ (germ. $82+4 \%$, tsw $6.72 \mathrm{~g}$ ). Chemical weed control was done once using dinoseb (Aretit $3 \mathrm{l} / \mathrm{ha}$ ). The soil was organic clay $(\mathrm{LjS}), \mathrm{pH}\left(\mathrm{H}_{2} \mathrm{O}\right)$ was 6.9. Annual fertilization consisted of $18 \mathrm{~kg}$ nitrogen, $60 \mathrm{~kg}$ phosphorus and $108 \mathrm{~kg}$ potassium per hectare (Hiven-PK $600 \mathrm{~kg} / \mathrm{ha}$ ), which was applied once in spring. In 1983, 1987 and 1989 also $200 \mathrm{~kg} \mathrm{MgSO}_{4}$ per hectare was applied. In the seeding year the trial was harvested only once by sub-plot cutting times.

Establishment in the seeding year as well as the canopy density in the beginning of the growing seasons were measured. From the harvested yields, canopy height, dry matter yield, dry matter content, crude protein content and crude protein yield were measured. In 1983, 1988 and 1989, the crude fiber content and in 1988 and 1989, the botanical composition were determined. The number of shoots $/ 50 \mathrm{~cm} \times 25 \mathrm{~cm}$ area was counted at two sites in each plot at the end of the experiment in June 1990.

The statistical analyses were done using the MSTAT program. The missing values were estimated and the degrees of freedom of subplots were reduced respectively.

\section{Results}

\section{Sowing year}

The emergence of plots was even, the average plant density being 368 shoots $/ \mathrm{m}^{2}$. The average yield remained low, only $1500-1900$ $\mathrm{kg}$ DM per hectare. The yield did not increase by delaying the cut. The highest yield was reached in the beginning of September. The average crude protein content was 18.7 and crude fiber content was $21.3 \%$, both without any significant change due to delaying the cut.

\section{Dry matter yield}

\subsection{Spring cut}

The yield increased by delaying the spring cut, the difference being significant between each cut*** (Table 1). Also the cutting time in the previous autumn had a significant*** effect on the spring yield: the later the autumn cut, the higher the spring yield.

\subsection{Autumn cut}

The yield of the autumn cut was affected significantly by the cutting time in spring*** and the cutting time in autumn***, and also by their interaction*. The first cutting in spring resulted in the highest autumn yield. The second cutting in autumn, beginning of September, gave the highest yield, $4300 \mathrm{~kg}$ DM per hectare, and the first cutting time, end of August, gave the lowest yield, $3300 \mathrm{~kg} \mathrm{DM}$ per hectare (Table 2).

The interaction between cutting times was significant. In the first cutting time in autumn, the cutting time in spring affected clearly the DM yield. In the case of the last autumn cut, 
Table 1. The effect of cutting time on the DM yield $(\mathrm{kg} / \mathrm{ha})$ of the spring cut. Averages of the years $1984-1989$. Yields marked with different letter in each column or row differ from each other $(\mathrm{P}<0.05$, Tukey's procedure).

\begin{tabular}{|c|c|c|c|c|c|}
\hline \multirow{2}{*}{$\begin{array}{l}\text { Cutting time in } \\
\text { the autumn }\end{array}$} & \multicolumn{5}{|c|}{ Cutting time in the spring } \\
\hline & 1st & 2nd & 3 rd & 4th & Mean \\
\hline 1st & 2460 & 3790 & 4450 & 4620 & $3830^{\circ}$ \\
\hline 2nd & 2870 & 4030 & 4920 & 5750 & $4400^{\mathrm{b}}$ \\
\hline 3 rd & 2990 & 4450 & 5170 & 5840 & $4610^{b}$ \\
\hline 4th & 3470 & 4720 & 5550 & 6470 & $5050^{\circ}$ \\
\hline Mean & $2950^{d}$ & $4250^{\mathrm{c}}$ & $5020^{\mathrm{b}}$ & $5670^{\mathrm{a}}$ & 4470 \\
\hline Days between cuts & & & & & \\
\hline Growth rate & & & & $\mathrm{ha} / \mathrm{day}$ & \\
\hline
\end{tabular}

F-value: Spring cut 136.49*** HSD $0.05385 \mathrm{~kg}$

Autumn cut $36.48 * * *$ HSD $0.05315 \mathrm{~kg}$

Interaction $\quad 1.37 \mathrm{~ns}$

Table 2. The effect of cutting time on the DM yield $(\mathrm{kg} / \mathrm{ha})$ of the autumn cut. Averages of the years $1984-1989$. Yields marked with different letter in each column differs from each other $(\mathrm{P}<0.05$, Tukey's procedure).

\begin{tabular}{llllll}
\hline $\begin{array}{l}\text { Cutting time in } \\
\text { the autumn }\end{array}$ & \multicolumn{5}{c}{ Cutting time in the spring } \\
\cline { 2 - 6 } & $1 \mathrm{st}$ & 2nd & $3 \mathrm{rd}$ & 4 th & Mean \\
\hline 1st & $4020^{\mathrm{b}}$ & $3370^{\mathrm{b}}$ & $2890^{\mathrm{c}}$ & $2900^{\mathrm{b}}$ & $3300^{\mathrm{c}}$ \\
2nd & $4620^{\mathrm{a}}$ & $4330^{\mathrm{a}}$ & $4220^{\mathrm{a}}$ & $4040^{\mathrm{a}}$ & $4300^{\mathrm{a}}$ \\
3rd & $4250^{\mathrm{ab}}$ & $3790^{\mathrm{b}}$ & $3820^{\mathrm{ab}}$ & $3840^{\mathrm{a}}$ & $390^{\mathrm{b}}$ \\
4th & $3870^{\mathrm{b}}$ & $3820^{\mathrm{ab}}$ & $3590^{\mathrm{b}}$ & $3870^{\mathrm{a}}$ & $3790^{\mathrm{b}}$ \\
\hline Mean & $4190^{\mathrm{a}}$ & $3830^{\mathrm{b}}$ & $3630^{\mathrm{b}}$ & $3660^{\mathrm{b}}$ & 3830 \\
\hline
\end{tabular}

F-value: Spring cut $11.59 * * *$ HSD $0.05290 \mathrm{~kg}$

Autumn cut $35.23^{* * *}$ HSD $0.05261 \mathrm{~kg}$

Interaction 2.48* HSD $0.05522 \mathrm{~kg}$

the cutting time in spring did not have such a strong effect. The last spring cut combined with the first autumn cut gave the lowest yield, while the highest yield in the autumn cut was reached by the first cutting in spring and the second in autumn.

\subsection{Average total yield}

Though the yields varied significantly between the years***, the variation remained small, the coefficient of variation being only $5.9 \%$. The highest average yield, $9000 \mathrm{~kg}$ DM, was reached in the last experimental year, 1989, and the lowest, $7680 \mathrm{~kg}$ DM per hectare, in 1986.

The time of both cuttings affected significantly*** the total yield, but showed, however, no interaction. The time of the spring cut was predominant in the total DM yield. The total DM yield increased from 7140 to $9330 \mathrm{~kg}$ per hectare by delaying the first cut, the difference between each cutting time being significant $(\mathrm{P}<0.05)$. Of the autumn cuts, only the first cutting time in autumn differed from the others, being the worst choice. The highest yield, $10340 \mathrm{~kg}$ DM, was reached by the latest cutting time in both cuttings (Table 3, Fig. 1).

\section{Crude protein content}

\subsection{Spring cut}

The cutting time in autumn did not have any effect on the crude protein content of spring yield. The average crude protein con- 

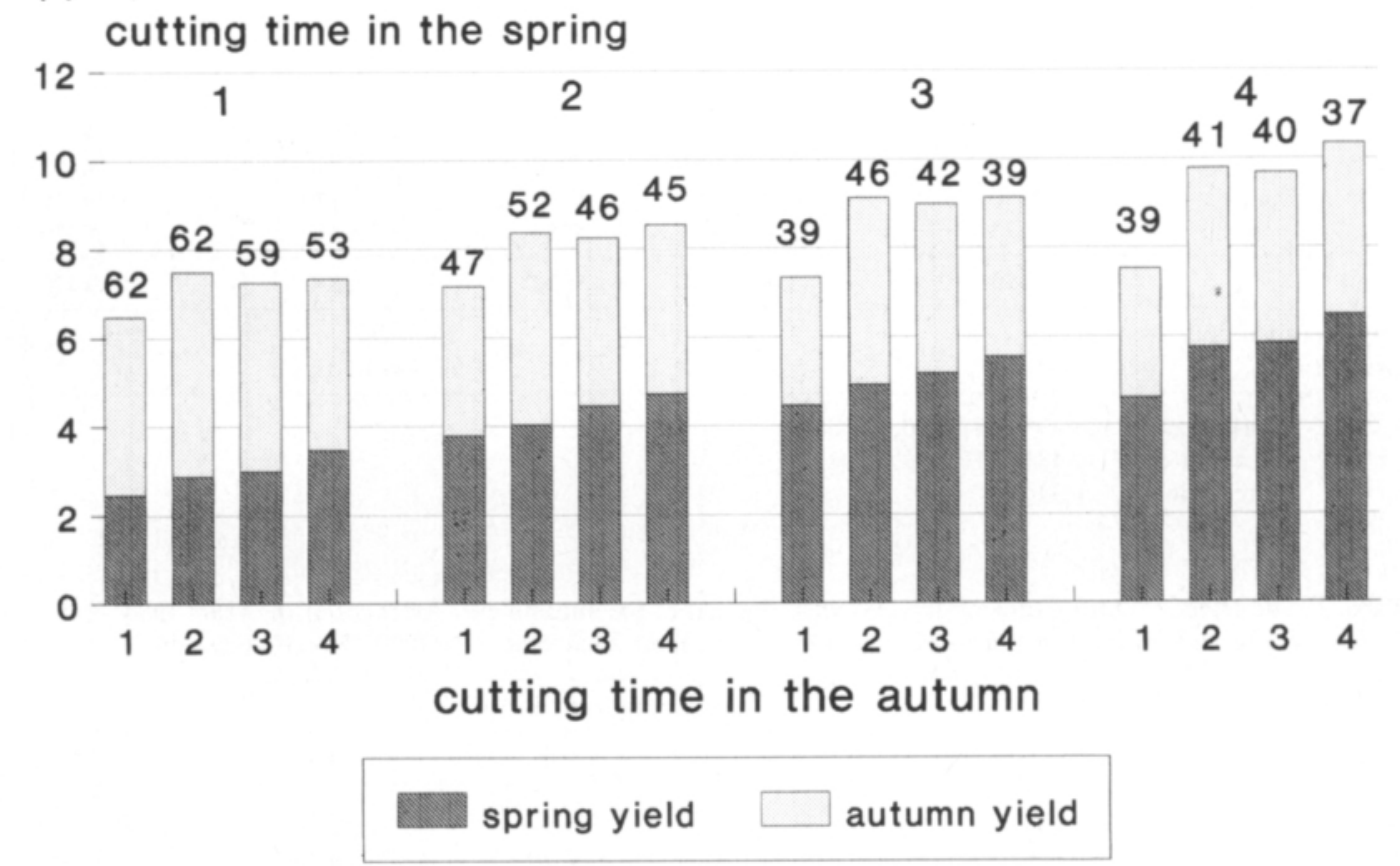

Fig. 1. Total DM yields of different cutting systems. Averages of the years 1984-1989. The figures on the top of the bars represent the proportion $(\%)$ of the second cut of the total yield.

tent was $20.2 \%$. The content decreased from 25.0 to $16.3 \%$ by delaying the spring cut (Fig. 2). The decrease of $C P$ was rather fast, depending on the developmental stage.

\subsection{Autumn cut}

The crude protein content was lower in the autumn cut than in the spring cut, the aver- age being $18.8 \%$. It was affected by cutting time in spring***, cutting time in autumn***, and cutting time interaction**.

The later the cut was done in autumn, the lower was the protein content (Fig. 2). Every cutting time in autumn differed from each other. On the other hand, the later the cut in spring, the higher was the protein content in the autumn yield. Every level of cutting times

Table 3. The effect of cutting time on the average annual DM yield ( $\mathrm{kg} / \mathrm{ha})$. Yields marked with different letter in each column or row differ from each other $(\mathrm{P}<0.05$, Tukey's procedure).

\begin{tabular}{|c|c|c|c|c|c|}
\hline \multirow{2}{*}{$\begin{array}{l}\text { Cutting time in } \\
\text { the autumn }\end{array}$} & \multicolumn{5}{|c|}{ Cutting time in the spring } \\
\hline & 1 st & 2nd & 3 rd & 4th & Mean \\
\hline 1 st & 6480 & 7160 & 7090 & 7520 & $7060^{b}$ \\
\hline 2nd & 7500 & 8360 & 9140 & 9790 & $8700^{\mathrm{a}}$ \\
\hline 3rd & 7240 & 8240 & 8990 & 9680 & $8540^{\mathrm{a}}$ \\
\hline 4th & 7340 & 8540 & 9140 & 10340 & $8840^{\mathrm{a}}$ \\
\hline Mean & $7140^{d}$ & $8080^{\circ}$ & $8590^{\mathrm{b}}$ & $9330^{\mathrm{aa}}$ & 8280 \\
\hline $\begin{array}{ll}\text { value: } & \text { Spring cut } \\
& \text { Autumn cut } \\
& \text { Interaction }\end{array}$ & $\begin{array}{l}47.30^{* * *} \mathrm{H} \\
25.25 * * * \mathrm{H} \\
1.31 \mathrm{~ns}\end{array}$ & $\begin{array}{l}5 \mathrm{~kg} \\
\mathrm{~kg}\end{array}$ & & & \\
\hline
\end{tabular}




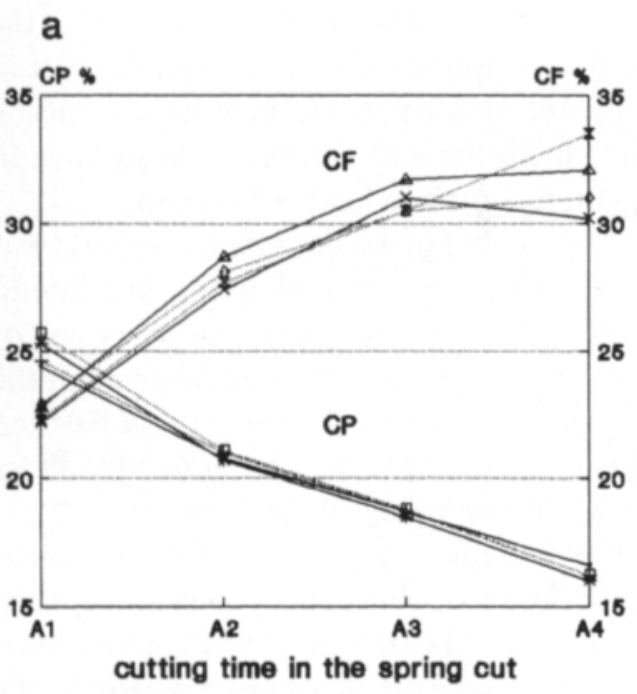

$-C P(B 1)+C P(B 2)-C P(B 3)-C P(B 4)$

$\rightarrow$ CF (B1) $\rightarrow$ CF (B2) - CF (B3) $-\mathrm{X}-\mathrm{CF}(\mathrm{B4})$

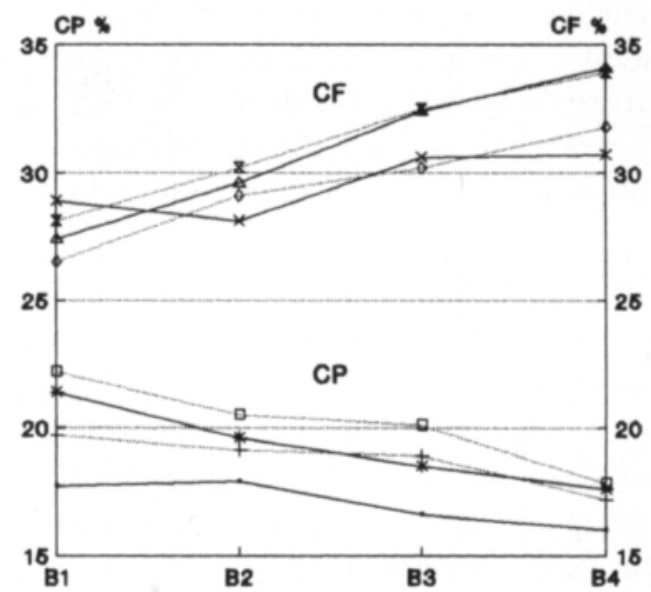

cutting time in the autumn cut

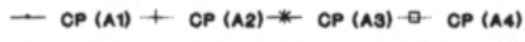

$\rightarrow$ CF (A1) $\rightarrow$ CF (A2) $\triangle$ CF (A3) $-\mathrm{X}-$ CF (A4)

Fig. 2. The crude protein 1984-1989 (CP) and crude fibre 1984, 1988-1989 (CF) content of the spring yield (a) and autumn yield (b). A1 = 1st cutting time in spring, B1 = 1st cutting time in autumn.

in spring differed from each other. The cutting time interaction was revealed because within the first cutting time in spring, the cutting time in autumn had hardly any effect (1.7\%-unit decrease), but within the last cutting time in spring the delay of the autumn cut had a clear effect (4.4\%-unit decrease) (Fig. 2). The effect of cutting time in autumn was generally smaller than the effect of cutting time in spring.

\section{Crude fiber content}

\subsection{Spring cut}

The crude fiber content was rather high, the average being $28.3 \%$. The effect of spring cutting time on the crude fiber content was significant***. The content increased with the developmental stages from $22.5 \%$ to $31.7 \%$. Differences between each cutting time were significant, except between the third and fourth cutting times (Fig. 2).

\subsection{Autumn cut}

The crude fiber content was even higher and the variation smaller in the autumn cut than in the spring cut. It was affected by the cutting time in spring*, the cutting time in autumn*** and by cutting time interaction***. The average content was $30.3 \%$.

The crude fiber content increased from 27.2 to $32.6 \%$ by delaying the cut. Differences between each cutting time were significant. The effect of the cutting time in spring was remarkable: the first and the second cutting time in spring gave a lower fiber content in the autumn yield than the latest cutting time. The cutting time interaction became significant because the content rose within the first cutting time in spring only slightly, but within the last cutting in spring the increase was clear (Fig. 2).

\section{Crude protein yield}

\subsection{Spring cut}

The average protein yield in the spring cut was $868 \mathrm{~kg}$ per hectare. It was affected by both cutting times***. The first cutting time gave the lowest protein yield, while the rest did not 
differ significantly from each other. The protein yield was also increased by delaying the autumn cut in the previous year through increased DM yield. Differences between cuts were significant, excluding the difference between the second and third cutting time.

\subsection{Autumn cut}

The average protein yield in the autumn cut was $714 \mathrm{~kg}$ per hectare. It was not affected by cutting time in the spring cut, but the time of the autumn cut affected siginificantly***. When cutting was done in the beginning of September (second cutting time), the crude protein yield was highest. The first and the last cutting times gave the lowest yields not differing from each other.

\subsection{Total crude protein yield}

Generally the crude protein yields were rather even and the management had only some effects*** on it: only the first cutting time, both in spring and in autumn, gave lower protein yields (Table 4). No interaction between cutting times was noticed.

\section{Results of botanical analyses}

\subsection{Botanical composition}

In total, yields contained $15 \%$ weeds in 1988 - 1989. The highest weed content ( $28 \%$ weeds) was reached by the combination of the second cutting time in spring and the first in autumn, while combination of the last cutting time in spring and the third cutting time in autumn contained only $3 \%$ weeds.

The amount of weeds in the spring yield was only affected by the cutting time in autumn. If the previous cutting was done at the end of August or in the beginning of September, the amount of weeds was higher $(17-18 \%)$ than if cutting was done at the end of September or in the beginning of the October $(9 \%)$.

In the autumn yield the amount of weeds was affected by both cutting times and by their interaction. The later the spring cut was done, the lower was the amount of weeds in the autumn yield. The decrease was from $25 \%$ weeds to $10 \%$ by delaying the spring cut. On the other hand, the first cutting time in autumn caused significant increase in the proportion of weeds compared to other cutting times. (26\% vs. $11-15 \%$ ). Cutting time interaction occurred because within the first cutting time in spring the cutting time in autumn had no effect at all.

\subsection{Goat's rue yield}

The goat's rue yield increased strongly by delaying both cuttings because of the increase of DM yield and the simultaneous decrease in weed content. The maximum goat's rue yield, $9620 \mathrm{~kg}$, was reached by combination of the

Table 4. The effect of cutting time on the total crude protein yield $(\mathrm{kg} / \mathrm{ha} / \mathrm{year})$. Yields marked with different letter in each column or row differ from each other $(\mathrm{P}<0.05$, Tukey's procedure).

\begin{tabular}{llllll}
\hline $\begin{array}{l}\text { Cutting time in } \\
\text { the autumn }\end{array}$ & \multicolumn{5}{c}{ Cutting time in the spring } \\
\cline { 2 - 6 } & 1st & 2nd & 3rd & 4th & Mean \\
\hline 1st & 1293 & 1446 & 1406 & 1410 & $1389^{\mathrm{b}}$ \\
2nd & 1529 & 1663 & 1745 & 1753 & $1672^{\mathrm{a}}$ \\
3rd & 1459 & 1634 & 1670 & 1717 & $1620^{\mathrm{a}}$ \\
4th & 1503 & 1655 & 1686 & 1725 & $1642^{\mathrm{a}}$ \\
\hline Mean & $1446^{\mathrm{b}}$ & $1599^{\mathrm{a}}$ & $1627^{\mathrm{a}}$ & $1651^{\mathrm{a}}$ & 1581 \\
\hline
\end{tabular}

$\begin{array}{lll}\text { F-value: } & \text { Spring cut } 18.90^{* * *} \text { HSD } 0.0581 \mathrm{~kg} \\ & \text { Autumn cut } 13.87^{* * *} \text { HSD } 0.05134 \mathrm{~kg} \\ & \text { Interaction } \quad 0.22 \mathrm{~ns}\end{array}$ 


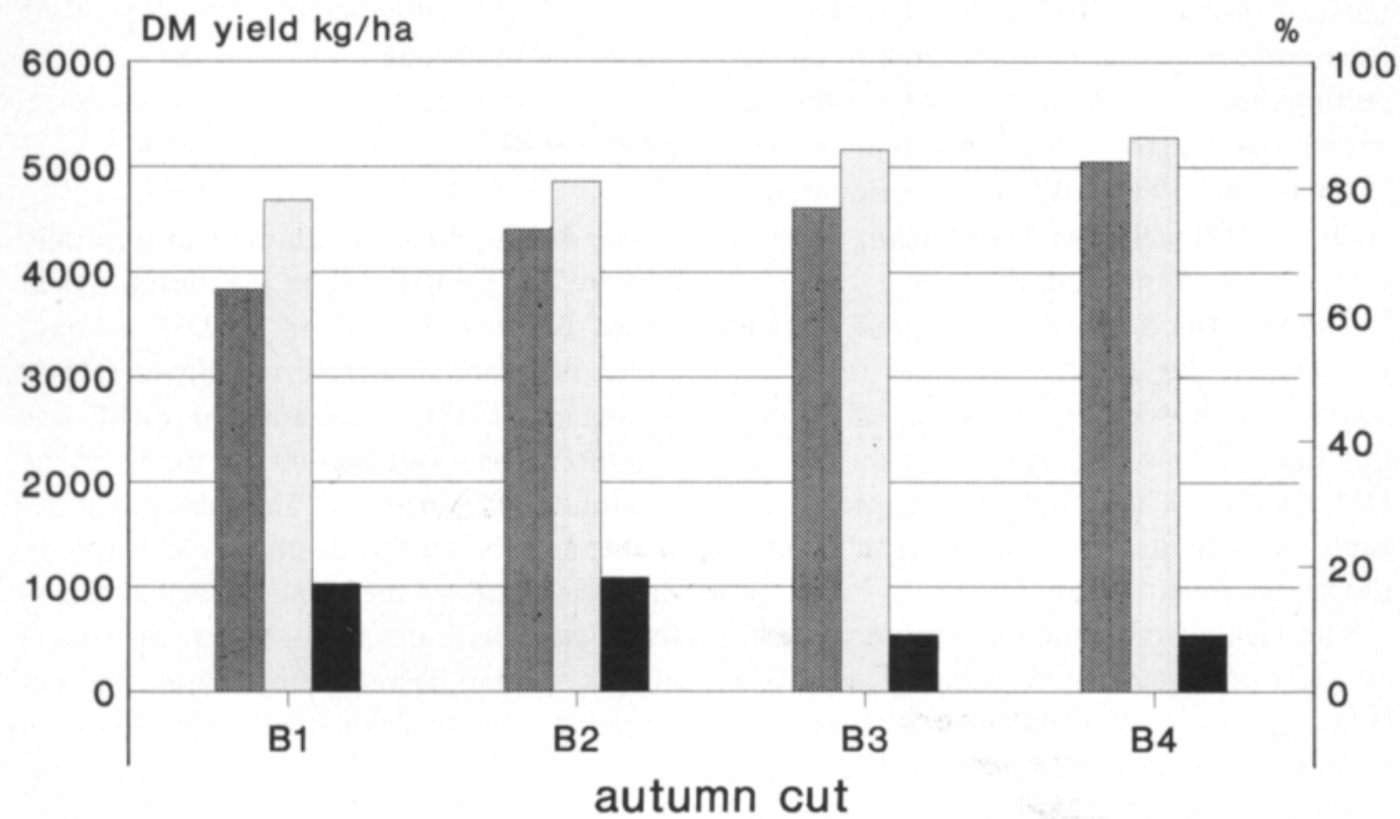

spring yield $\square$ sward density \% $\square$ amount of weeds $\%$

Fig. 3. The effect of cutting time in autumn on the following spring yield.

last cutting times of both cuttings, while the minimum, $5290 \mathrm{~kg}$, was reached by the combination of the first cutting time in spring and the second cutting time in autumn.

\section{Density of sward in spring}

The density was measured as percentages of the plot area. Both cutting times affected significantly***. The first cutting time in spring cut was the best and differed from the others. The latest cutting time was the worst choice, also differing from the others.

The plots cut by the first two cutting times in autumn had a lower density than the plots with two later cutting times (Fig. 3). The interaction occurred because within the second cutting time in spring the cutting time in autumn did not have any effect.

At the end of the experiment the average shoot density was 286 shoots $/ \mathrm{m}^{2}$. The density was affected only by the cutting time in the spring cut: the highest density, 345 shoots/ $\mathrm{m}^{2}$, was reached by the first cutting time and the lowest density, 230 shoots $/ \mathrm{m}^{2}$, by the last cutting time in spring.

\section{Discussion}

\section{Sowing year}

The shoot density in the sowing year was 394 shoots $/ \mathrm{m}^{2}$ which is near the optimum reported by RaIG (1980), $400-450$ shoots $/ \mathrm{m}^{2}$. The yield in the sowing year, $1500-1900 \mathrm{~kg} /$ ha, remained somewhat lower than in the experiments reported by MÄKÄRÄINEN et al. (1985) and VARIS (1986). The yield did not increase if the cut was delayed. RaIG (1980, 1988) observed that goat's rue develops a strong root system during the sowing year.

\section{Spring cut}

In the second year the growth of goat's rue is reported to start early. The rapid develop- 
ment in spring is also implicated by the early blooming: it started normally by the second cutting time, 5-16 June, which is $3-4$ weeks earlier than in red clover at Viikki in 1973 (SALo et al. 1975). By this developmental stage the DM yield was $4250 \mathrm{~kg} / \mathrm{ha}$, which is rather high considering the date.

The growth rate of the spring yield was 130 $\mathrm{kg} \mathrm{DM} / \mathrm{ha} /$ day during the most rapid development between the first and second cutting times. The average growth rate was $94 \mathrm{~kg}$ $\mathrm{DM} / \mathrm{ha} /$ day. These figures are nearly the same as calculated for red clover in Finland (NYKÄNEN-KURKI 1988).

The yields were similar to those of earlier trials on goat's rue conducted at Viikki (MÄKÄRÄINEN et al. 1985, VARIS 1986) but generally smaller than in Estonia (RAIG 1980, 1988) and somewhat higher than in Norway (LUNNAN 1989).

The crude protein content decreased between the first and the last cutting time in spring ( 29 days) by $0.30 \%$ units/day. This was somewhat faster than found earlier in Finland (MÄKÄRÄINEN et al. 1985, VARIS 1986). Compared to red clover, the rate was very similar: 0.28-0.33 (Pulli 1980, JönSSON 1981, FAGERBERG 1988, NYKÄNEN-KURKI 1988), $0.15-0.56$ (SAlo et al. 1975). The content was clearly higher in goat's rue than in red clover, in mid-early cut $20.9 \%$ vs. $15.4 \%$ (PULLI 1980) or of the same level (SALO et al. 1975).

The crude fiber content limits the use of goat's rue more than the changes in crude protein content. The optimum CF content for silage is $24-27 \%$ (HuOKUNA and HaKKola 1984). In the second cutting time in spring, the average crude fiber content was $27.9 \%$, while the protein content was still $20.9 \%$. Over the cutting period of 29 days in this experiment, the average increase was $0.32 \%$ units/day being $0.54 \%$ units/day during the period of the most rapid development. This was similar (HUOKUNA et al. 1985, SYRJÄLÄ et al. 1978) or lower (MelA 1975) compared to the development of grass leys in Finland. It is similar (SALo et al. 1975) or higher (NYKÄ-
NEN-KURKI 1988) compared to red clover 0.35 $-0.51 \%$ units/day.

\section{Autumn cut}

The development in autumn was naturally slower. The growth rate in the autumn yield varied between 31 and $58 \mathrm{~kg} \mathrm{DM} / \mathrm{ha} /$ day, which is rather similar to red clover (NYKÄNEN-KURKI 1988). The autumn yield was highest by the second cutting time, in the beginning of September. The subsequent decrease may be due to death of old leaves in the lowest part of the stand as well as transfer of carbohydrates to the roots for wintering. A similar decrease in autumn has occurred in other trials on goat's rue (MÄKÄRÅINEN et al. 1985) and also in trials on grass (HaKkola et al. 1987). However, the spring yield increased by delaying the autumn cut and so in the total yield there was no statistical difference between the second, third and the fourth cutting times in autumn.

The CP content decreased by $0.09 \%$ units/ day, which is slightly more compared to red clover (NYKÄNEN-KURKI 1988) or to clovergrass (Pulli 1980), and slightly less than for red clover stands reported by JönSsON (1981), and clearly less than for grass stands in Finland (SYrJÄLÄ et al. 1978, Huokuna and HaKKOLA 1984).

The CF content was rather high, the average being $30.3 \%$, but the increase was slower than in the spring cut: $0.14 \%$-units/day between the first and the last cutting times in autumn. The increase is more similar to that of grass leys (SyrJäLÅ et al. 1978, HUOKUNA and HaKKola 1984), while NyKÄNEN-KURKI (1988) found no clear increase of CF in red clover.

A high CF content was observed in 1984, average content 35.5 in autumn cut, while it was 29.7 and 25.5 in 1988 and 1989 , respectively. In these two years there was a cessation in growth after the first cut due to drought.

It may be concluded that the development of goat's rue is similar to that of red clover 
as far as growth rate and crude protein content are concerned. However, the development of crude fiber content is more similar to grasses.

The crude protein yield, $1300-1750 \mathrm{~kg} / \mathrm{ha}$, was fairly good, while it was produced with $18 \mathrm{~kg}$ nitrogen per hectare, only. It was good compared to red clover trials in Finland, 1200 $-1500 \mathrm{~kg} / \mathrm{ha}$ (HUOKUNA and HAKKOLA 1984, NYKÄNEN-KURKI 1988).

\section{Cutting schedule}

The crude fiber content is more critical to the quality of the yield than crude protein content. In order to compromise the quality and the quantity, the first cut should be done by the time of 10-50\% blooming (approximately at the second cutting time in this experiment). This was also suggested by VARIS (1986).

Thus, the best second cut is from the second week of September to the first week of October. The later the cut, the better density and smaller amount of weeds were reached together with higher spring yield (Fig. 3). However, the CF content tends to be too high in late cuts, and also the maximum autumn yield was reached normally during the second week of September.

According to this trial, considering the recommended cutting system, a yield of $8360 \mathrm{~kg}$ DM per hectare per year was reached. The pooled CP content of the yield was $19.9 \%$ and the CP yield was $1660 \mathrm{~kg} / \mathrm{ha}$. The CF content was in the first cut 27.9 and in the second cut $29.1 \%$. The amount of weeds in the five to six year leys was $12-18 \%$.

It is clear that the cutting optimum differs from that of red clover (Fig. 4). However, in 1988 and 1989, the lack of rainfall after second cutting time in spring was the reason for the small yields of the recommended cutting system (Fig. 4). Despite this, the annual variation of yield of the recommended cutting management remained small, C.V. $8.7 \%$ compared to the variation in silage leys in the southern coast of Finland, C.V. 20-30\% (Mukula et al. 1981).

It is suggested by RAIG $(1980,1988)$ and VARIS (1986) that the period between the first and the second cut is important for regrowth. In this experiment the actual cutting times were important: within the earliest cutting time in spring, the extension of the cutting interval from 88 to 123 days did not help the poor yield (Fig. 5). On the other hand, the first cutting time in autumn gave poor yields in any case. In the case of the last cutting time in spring (A4), the cutting interval of 60 days seemed to be too short, but 70 days enough, as also suggested by VARIS (1986).

\section{Persistence of goat's rue ley}

The poor persistence of legumes is the most critical factor in their cultivation in Finland. Normally, red clover stands remain satisfactory for two-three years (Mela et al. 1980, Kurtto 1982, Pulli and Turtola 1983, Huo. KUNA et al. 1985).

The growing seasons as well as winters differed very much from each other in 1983 -1989 . The good persistence of goat's rue was shown in this study. The yield of A4B4 management had even a slight trend to increase, but the quality of the yield was not satisfactory. The yield of the recommended cutting system remained stable, especially when compared to red clover or grass leys in Finland. The better persistence compared to red clover is also reported by RAIG (1980, 1988), MĂKĂRĂINEN et al. (1985), VARIS (1986) and LunNan (1989). This might be due to lack of diseases in a new crop. Furthermore, its overwintering underground as stolons is advantageous. Later these stolons became independent of the initial individual and so the plant fills the available area effectively.

Despite some negative characteristics, e.g. slow initial growth in the sowing year as well as high crude fiber content, goat's rue may be a promising forage legume for northern conditions. Its persistence and yield capacity 


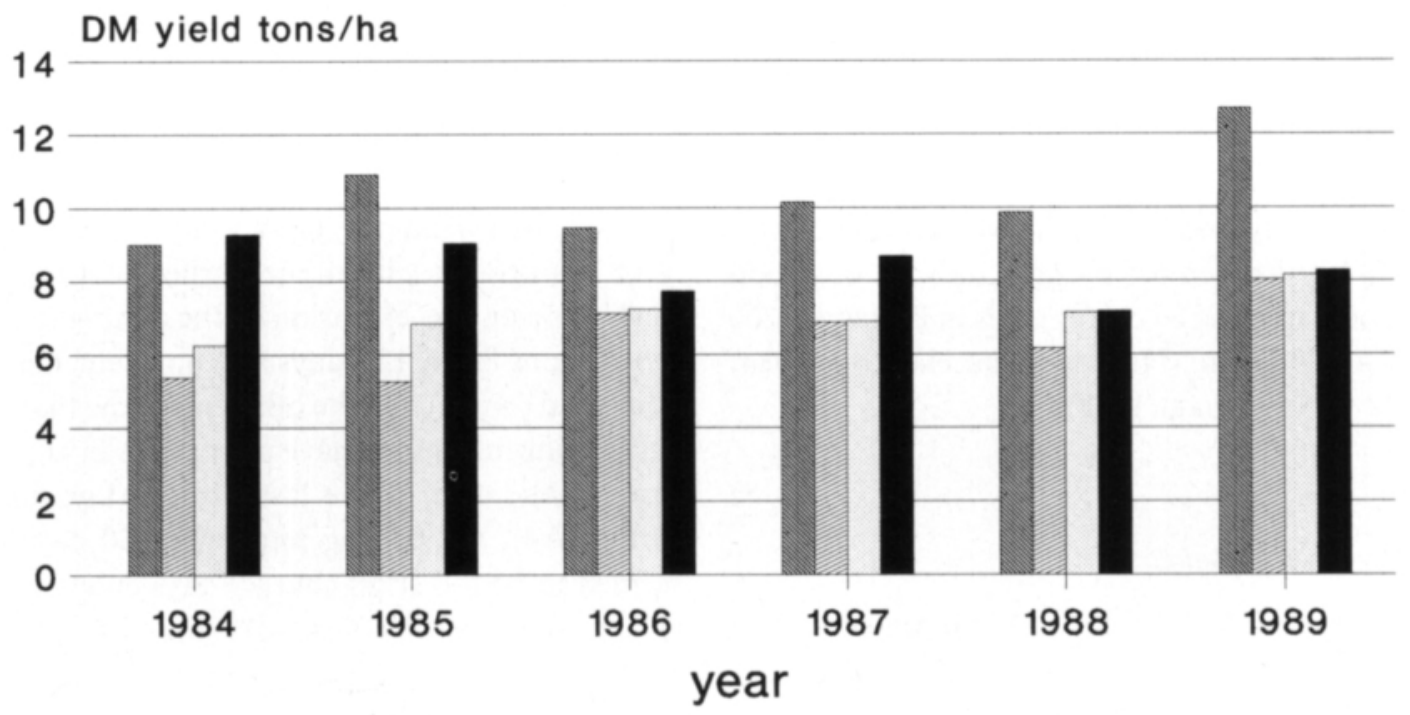

cutting system

maximum A4B4

\%inimum A1B1

cut as clover A3B1

recommended $\mathrm{A} 2 \mathrm{~B} 2$

Fig. 4. The total DM yields of four different cutting managements $1984-1989$. A1B1 = the first cutting time in spring and autumn. A4B4 = the last cutting time in spring and autumn.

\section{DM yield tons/ha}
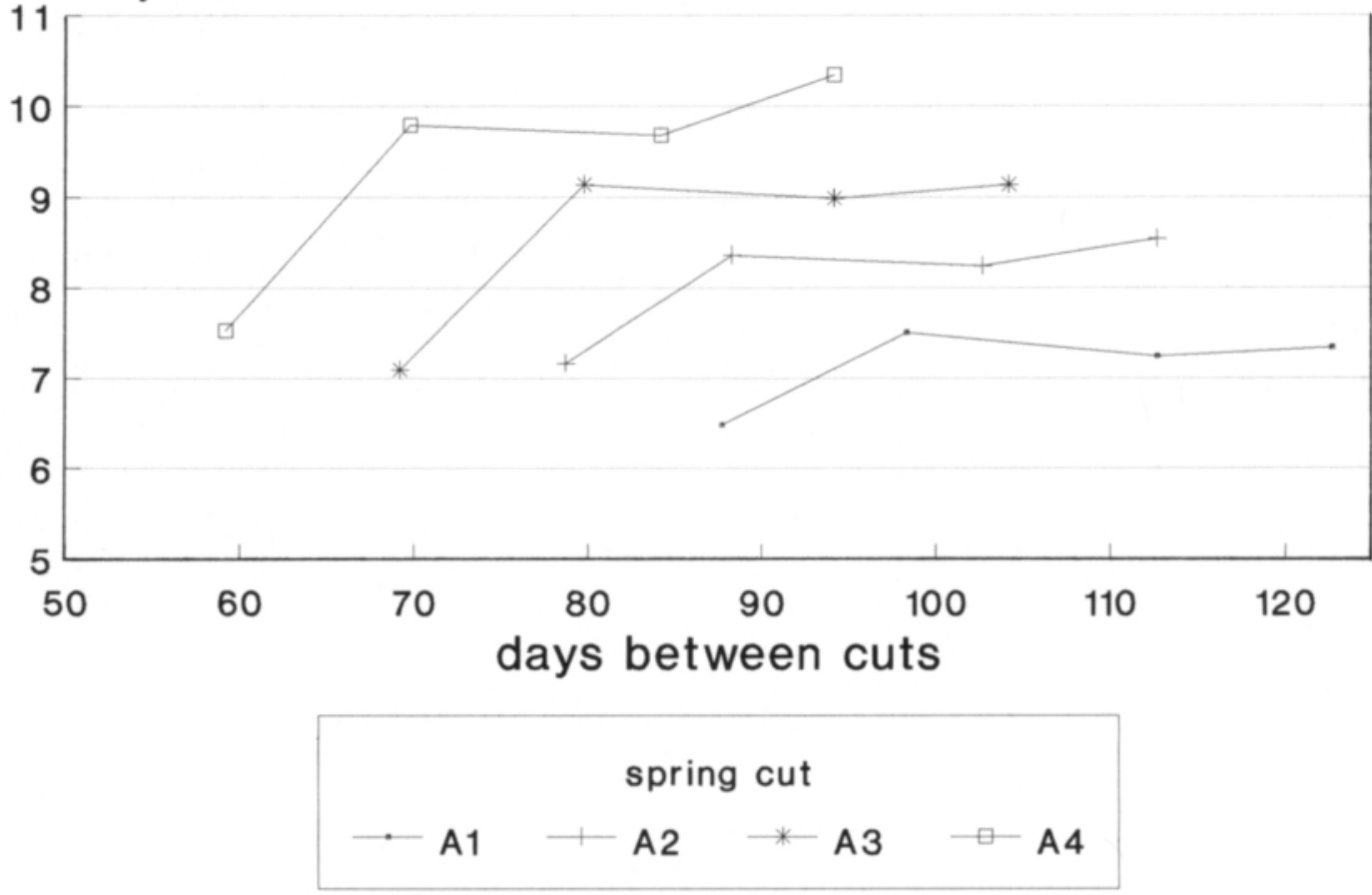

Fig. 5. The DM yields of four different cutting times in spring related to the cutting interval between spring and autumn cut. $\mathrm{A} 1 \mathrm{l}=$ the first cutting time in spring. 
should be evaluated in Central Finnish conditions, in pure and mixed stands.

\section{References}

FAGerberg, B. 1988. The change in nutritive value in timothy, red clover and lucerne in relation to phenological stage, cutting time and weather conditions. Acta Agr. Scand. 38: 347-362.

Hakkola, H., Heikkilä, R., Rinne, K. \& Vuorinen, M. 1987. Odelman typpilannoitus, săngenkorkeus ja niittoaika. Maatalouden tutkimuskeskuksen tiedote 4/87.

Huokuna, E. \& HaKkola, H. 1984. Koiranheinän ja timotein kasvu ja rehuarvon muutokset săilörehuasteella. Maatalouden tutkimuskeskuksen tiedote $8 / 84$.

-, Järvi, A., Rinne, K. \& TAlvitie, H. 1985. Nurmipalkokasvit puhtaana kasvustona ja heinäseoksena. Maatalouden tutkimuskeskuksen tiedote $22 / 85$.

Jónsson, N. 1981. Kvalitetsförändringar hos vallvăxter. Resultat från skördetidsförsők med olika arter och sorter. Swedish University of Agricultural Sciences, Department of Plant Husbandry. Rapport 93.

KURTTO, J. 1982. Palkokasvien viljelyvarmuus. Esitutkimus. Biologisen typensidonnan ja ravinnetypen hyvăksikäytön projekti. Suomen itsenäisyyden juhlavuoden 1967 rahasto. Julkaisu 2, 78 p.

LaAkso, I., Virkajărvi, P., Airaksinen, H. \& Varis, E. 1990. Determination of vasicine and related alkaloids by gas chromatography-mass spectrometry. J. Crom. 505: 424-428.

LunNan, T. 1989. Raudklover, kvitklover, luserne og kaukasisk strekbelg i blanding med timotei og i reinbestand. Norsk landbruksforsking 3: 25-38.

MELA, T. 1975. Skördetidens betydelse för vallgräsets skörd och dess kvalitet. Nordisk Jordbruksforskning 57: $183-184$.

-, Huokuna, E., Koylujărvi, J., Rinne, K., Sıмojokı, P. \& Teittinen, P. 1980. Comparison between nordic red clover varieties in clovergrass mixtures. Ann. Agric. Fenn. 19: 131-141.

Mukula, J., Rantanen, O. \& Ravantti, S. 1981. Heinăn
Acknowledgements. The authors wish to thank Tarja Kortesmaa, M. Sc., and Helena Airaksinen, M. Sc., for supervising the field trial. ja săilörehun tuotannon satovaihtelut ja riskialttius Suomessa 1950-1978. MTTK:n kasvinviljelylaitoksen tiedote 17.

MăkĂrÄıInen, E., Kansanen, P., KortesmaA, T. \& Varis, E. 1985. Rehuvuohenherneen viljelyominaisuudet ja käyttőarvo. Biologisen typensidonnan ja ravinnetypen hyvăksikăytoon projekti. Suomen itsenăisyyden juhlavuoden 1967 rahasto. Julkaisu 14, 72 p.

NYKĀNEN-KURKı, P. 1988. Apilaseosnurmen sadon mäărăn ja laadun muutokset kasvukauden aikana. Pro gradu tyő, kasvinviljelytieteen laitos. 78 p.

Pulli, S. 1980. Growth factors and management technique used in relation to the developmental rhythm and yield formation pattern of a clover grass stand. J. Sci. Agr. Soc. Finl. 52: 215-280.

- \& Turtol.A, A. 1983. Puna-apilan menestyminen ja viljelytekniikka suomalaisilla maatiloilla. Biologisen typensidonnan ja ravinnetypen hyväksikäytön projekti. Suomen itsenäisyyden juhlavuoden 1967 rahasto. Julkaisu 3, 159 p.

RAIG, H. 1980. Sőodagaleega kasvatamine ja kasutamine. Tallinna, Valgus. 64 p.

- 1988. Sőodagaleega kasvatamise kogemusi, Tallinna, Valgus. 117 p.

Salo, M-L., Nykänen, A. \& Sormunen, R. 1975. Nurmikasvien koostumus, pepsiini- $\mathrm{HCl}$-liukoisuus ja in vitro -sulavuus eri kasvuasteilla. J. Sci. Agr. Soc. Finl. 47: $480-490$.

Syrjālā, L., Suvitie, M. and Seppālā, J. 1978. Timoteinurmen sato, koostumus ja sulavuus kasvukauden eri aikoina. Kehittyvã Maatalous 39: 27 -35 .

VARIS, E. 1986. Goat's rue (Galega orientalis Lam.), a potential pasture legume for temperate conditions. J. Agr Sci. Finland 58: 83-101.

Ms received March 22, 1991 


\section{SELOSTUS}

\section{Niittoajan vaikutus rehuvuohenhernenurmeen}

\section{Perttu Virkajärvi ja Eero Varis}

Helsingin Yliopisto,

Kasvinviljelytieteen laitos

Helsingin yliopiston kasvinviljelytieteen laitoksella Viikissă järjestettiin 1983-1989 rehuvuohenherneen (Galega orientalis Lam.) niittoaikakoe. Tarkoituksena oli selvittäă kevään ja syksyn niittoaikojen vaikutus puhtaan rehuvuohenhernekasvuston sadon mäăräăn ja laatuun sekả toisaalta nurmen kuntoon. Kevään niittoajat olivat: 1) kesäkuun alku, 2) kesäkuun puolivăli, 3) kesäkuun loppu ja 4) heinäkuun alku. Vastaavasti syksyn niittoajat olivat 1) elokuun loppu, 2) syyskuun alku, 3) syyskuun loppu ja 4) lokakuun alku.

Rehuvuohenherne săilyi nurmissa hyvin. Vielä viimeisenă eli kuudentena satovuonna kokeen keskisato oli 9000 kg kuiva-ainetta hehtaaria kohden. Rikkaruohojen osuus v. 1988-89 sadoissa oli keskimäärin $15 \%$ ja parhaimmalla koejäsenellă vain $3 \%$.

Rehuvuohenherne aloitti kasvunsa aikaisin ja saavutti kukinta-asteen keskimăărin jo kesăkuun puolivăliin mennessä. Muutoin sen sadon kasvunopeus ja muutokset raakavalkuaispitoisuudessa olivat puna-apilaa vastaavia. Kuitenkin raakakuitupitoisuus nousee herkästi liian korkeaksi ja sen kehitys onkin samankaltainen kuin useilla heinillă. Năin raakakuitupitoisuus muodostuu hallitsevaksi tekijăksi parasta niittoajankohtaa valitessa.

Tämän kokeen tulosten perusteella suositeltava niittoaika Etelä-Suomessa on kevaaallaa kukinnan alussa (n. 10 $-50 \%$ kukinta) eli kesäkuun puolivălissä. Syysniiton optimaalisin aika on syyskuun toisella viikolla. Edellä kuvatulla käsittelyllă saatiin kokeessa kuuden vuoden keskiarvoina 8360 kg:n kuiva-aine- ja 1660 kg raakavalkuaissato hehtaaria kohden. Sadon painotettu Rvpitoisuus oli $19.9 \%$. Raakakuitupitoisuus oli kevătsadossa $27.9 \%$ ja syyssadossa $29.1 \%$. Rikkaruohojen osuus v. $1988-89$ oli $12-18 \%$.

Huolimatta hitaasta alkukehityksestä ja korkeahkosta kuitupitoisuudesta kylvövuonna vuohenherne on lupaava tulokas nurmipalkokasvivalikoimaamme. 